\title{
Tsunami heights and damage along the Myanmar coast from the December 2004 Sumatra-Andaman earthquake
}

\author{
Kenji Satake ${ }^{1}$, Than Tin Aung ${ }^{1}$, Yuki Sawai ${ }^{1}$, Yukinobu Okamura ${ }^{1}$, Kyaw Soe Win ${ }^{2}$, Win Swe ${ }^{3}$, Chit Swe ${ }^{4}$, Tint Lwin Swe ${ }^{4}$, \\ Soe Thura Tun ${ }^{5}$, Maung Maung Soe ${ }^{6}$, Thant Zin $\mathrm{Oo}^{6}$, and Saw Htwe Zaw ${ }^{7}$ \\ ${ }^{1}$ Geological Survey of Japan, AIST, Tsukuba, Ibaraki 305-8567, Japan \\ ${ }^{2}$ Graduate School of Earth and Environmental Studies, Nagoya University, Nagoya 464-8602, Japan \\ ${ }^{3}$ Myanmar Geoscience Society, Yangon, Myanmar \\ ${ }^{4}$ Dept. Engineering Geology, Yangon Technological University, Yangon, Myanmar \\ ${ }^{5}$ University of Yangon, Yangon, Myanmar \\ ${ }^{6}$ Department of Meteorology and Hydrology, Yangon, Myanmar \\ ${ }^{7}$ Myanmar Engineering Society, Yangon, Myanmar
}

(Received June 17, 2005; Revised November 4, 2005; Accepted November 4, 2005; Online published February 17, 2006)

\begin{abstract}
The tsunami heights from the 2004 Sumatra-Andaman earthquake were between 0.4 and $2.9 \mathrm{~m}$ along the Myanmar coast, according to our post tsunami survey at 22 sites in Ayeyarwaddy Delta and the Taninthayi coast. Interviews to coastal residents indicate that the tsunami heights were lower than high tide level in rainy season, probably by storm surge. They also testified that the arrival times were between 2 and 5.5 hours after the earthquake but the reliability may be low because nobody felt ground shaking. Much smaller tsunami than the neighboring Thai coast, where the tsunami heights were 5 to $20 \mathrm{~m}$, explains relatively slighter tsunami damage in Myanmar; the casualties were reported as 71, compared to about 8300 in Thailand. The smaller tsunami was probably due to the fact that the main tsunami source did not extend to Andaman Islands. The tsunami travel times and maximum heights computed from a $700 \mathrm{~km}$ long source are basically consistent with the observations. For a nearby tsunami source, the tsunami hazard would be more significant in Myanmar, because coastal houses are unprotected for tsunamis and no infrastructure exists to disseminate tsunami warning information.
\end{abstract}

Key words: Sumatra-Andaman earthquake, tsunami, field survey, Andaman Sea, Myanmar, Thailand.

\section{Introduction}

A giant earthquake occurred off Sumatra Island of Indonesia, at 00:58:53 UTC (07:28 Myanmar time) on December 26, 2004. The earthquake was the largest in size (Mw 9.1-9.3) in the last 40 years in the world, since the 1960 Chilean earthquake (Mw 9.5). The earthquake was an interplate event, caused by the subduction of Indian (or Indo-Australian) plate beneath Andaman (or Burma) microplate (Lay et al., 2005). While the epicenter was located west off Sumatra Island, the aftershock zone extended through Nicobar to Andaman Islands, the total length being more than 1,000 km (Fig. 1).

This earthquake generated a tsunami which devastated the shores of Indonesia, Sri Lanka, South India, Thailand, and as far as the east coast of Africa. More than 200,000 people are thought to have died as a result of the tsunami. The number of victims (International Federation of Red Cross and Red Crescent Societies, 2005), is the largest in Indonesia $(\sim 164,000)$, followed by Sri Lanka $(\sim 36,000)$, India $(\sim 16,000)$, Thailand $(\sim 8,300)$, and reported as far as from Somalia ( 300). In Myanmar, the damage and casualties (71) are relatively small compared to the above countries.

Copyright (c) The Society of Geomagnetism and Earth, Planetary and Space Sciences (SGEPSS); The Seismological Society of Japan; The Volcanological Society of Japan; The Geodetic Society of Japan; The Japanese Society for Planetary Sciences; TERRAPUB
For the scientific studies of tsunamis, coastal damage and wave height are the basic data to be collected. This paper is to summarize the survey results to document the effect of tsunami along the Myanmar coast. The post tsunami survey in Myanmar is particularly important to identify (1) why the tsunami damage was much smaller than the neighboring Thai coast, and (2) vulnerability of the Myanmar coast for future tsunamis.

\section{Method and Tide Correction}

The tsunami survey along the Myanmar coastal area was carried out from March 7 through 15, 2005 in Dawei, Kawthaung and Myeik areas along the Taninthayi coast and in Ayeyarwaddy Delta (Fig. 1).

In the field, following general procedure was adopted for the survey (Intergovernmental Oceanographic Commission, 1998). (1) collect relevant available data and information, existing maps, charts, tidal records; (2) interview with local people; (3) take pictures of the present condition; (4) record the location by a portable GPS; (5) measurements of level and distance of maximum flood level; and (6) measurements of level and distance of the wave front at the time of measurement.

The tsunami heights were measured on the basis of various indicators (Fig. 2), and we rank their reliabilities (Table 1). When physical evidence such as watermarks or debris were found, and endorsed by eyewitness accounts, the 


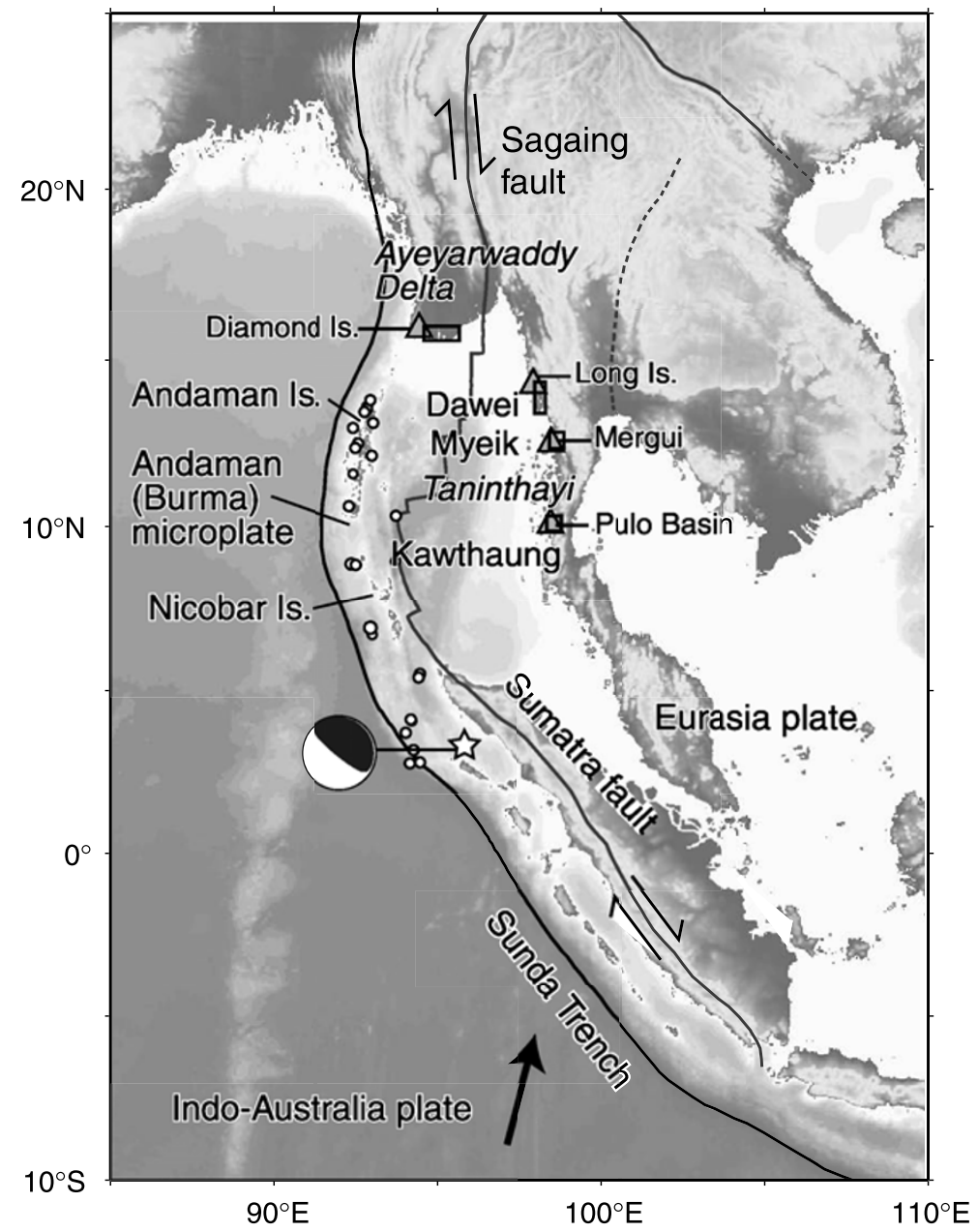

Fig. 1. Tectonic map showing the epicenter of the Sumatra-Andaman earthquake and aftershock distribution (circles; within 24 hours of the mainshock according to U.S.G.S.). The focal mechanism of the mainshock (Harvard CMT solutions) is also shown. Squares are the approximate locations for enlarged maps of Fig. 5. The triangles show the locations where the tide levels are computed for the correction.

reliability is high (rank A). When accounts are based only on memories of eyewitness, the reliability is considered as lower (rank B).

For the measurements of the tsunami heights, we used a handheld laser ranging instrument (Impulse 200LR; Laser Technology Inc.) and an auto-level equipment. In general, auto-level with the tripod provides more accurate heights than the laser instrument without tripod, while the laser instrument provides quicker results for a long distance $(>100 \mathrm{~m})$. For measurements of a short distance, we used both instruments. The vertical difference between them is at most $20 \mathrm{~cm}$. For measurements of longer distance, we used only laser instrument.

We measured the height of tsunami traces (debris or watermarks) above the sea level at the time of measurement. Tsunami heights were calculated as follows:

$$
T h=(T t-T m)+(T m-T a)
$$

where $T h$ is the estimated tsunami height, $T t$ is the height of tsunami trace, $T m$ the tidal level at the time of measurement, and $T a$ the computed tide at the time of tsunami on December 26, 2004 (Figs. 3 and 4). We indicate times in 24 hour system (e.g., 13:13) on Myanmar local time when they are accurate to the nearest minute.
The tide levels at the times of tsunami arrival and the measurement were computed on the basis of astronomical tides, by using computer program WXTide 32 release 4. The maximum differences of the predicted tides with a tide table (United Kingdom Hydrographic Office, 2004) are within 70 minutes and $50 \mathrm{~cm}$ at ebb/flood times. For Ayeyarwaddy Delta, tide was calculated based on predicted tides at Bassein River, Diamond Island $\left(15^{\circ} 52.0^{\prime} \mathrm{N}\right.$, $\left.94^{\circ} 17.0^{\prime} \mathrm{E}\right)$. For Dawei coast, the tide was calculated at Heinze Bok, Long Island $\left(14^{\circ} 24.0^{\prime} \mathrm{N}, 97^{\circ} 47.0^{\prime} \mathrm{E}\right)$. For Myeik measurements, the tide was calculated at Mergui $\left(12^{\circ} 26.0^{\prime} \mathrm{N}, 98^{\circ} 35.9^{\prime} \mathrm{E}\right)$. For the measurements around Kawthaung, tide was calculated at Pulo Basin $\left(9^{\circ} 59.0^{\prime} \mathrm{N}\right.$, $\left.98^{\circ} 29.0^{\prime} \mathrm{E}\right)$.

Based on interviews to eyewitnesses, we recorded arrival time of the tsunamis (December 26, 2004) at each surveyed site. As described below, the tsunami arrival times from interview to coastal residents vary within the neighboring locations. We felt that such variation in arrival time is dependent on the interviewee, rather than the local effects of tsunami. We indicate the reported time to the nearest quarter hour with am or pm. We assume that the tsunami arrival was 11:00 am for the Taninthayi coast and 11:30 for Ayeyarwaddy Delta to make the corrections. 


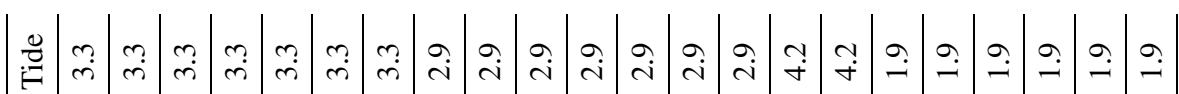

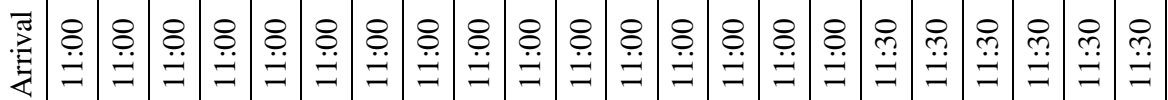

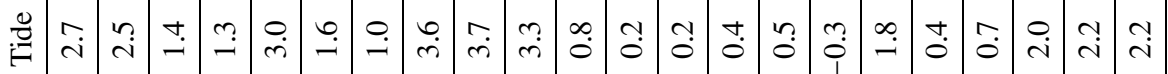

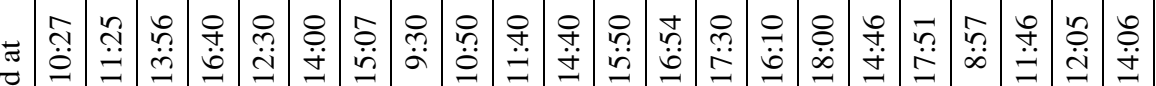
党

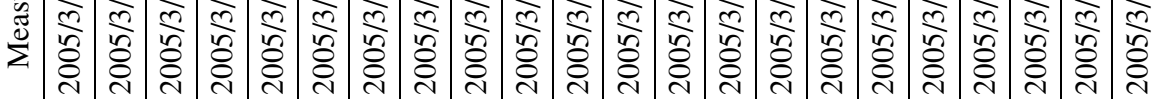

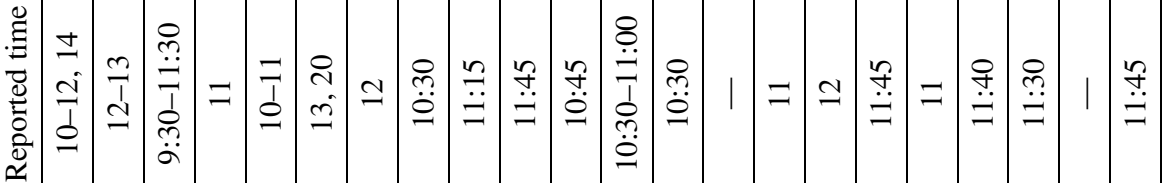

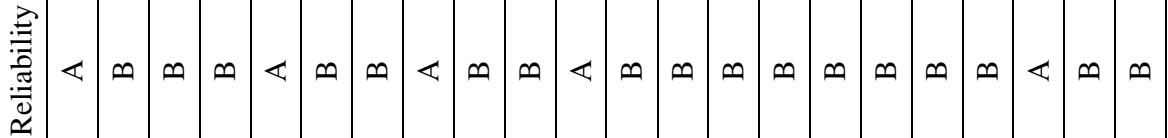

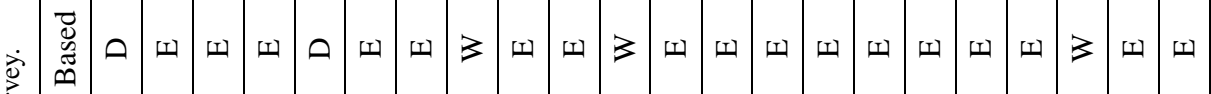
竞

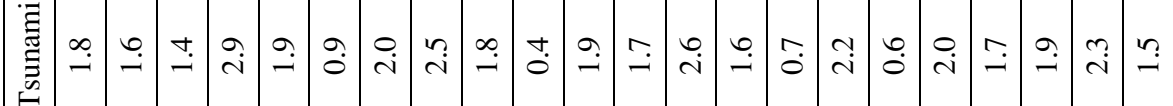

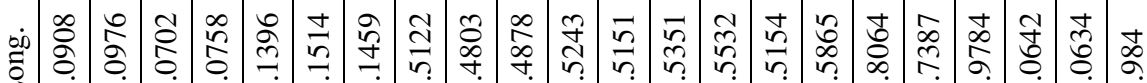

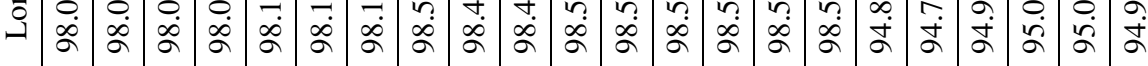

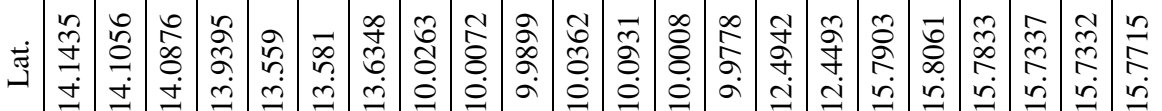

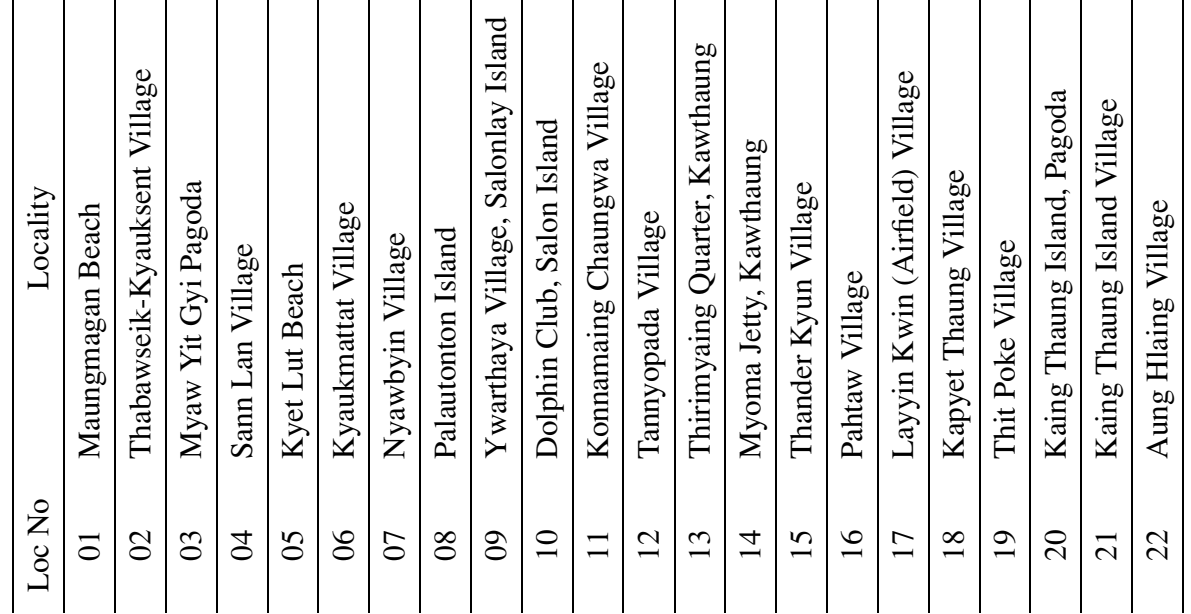



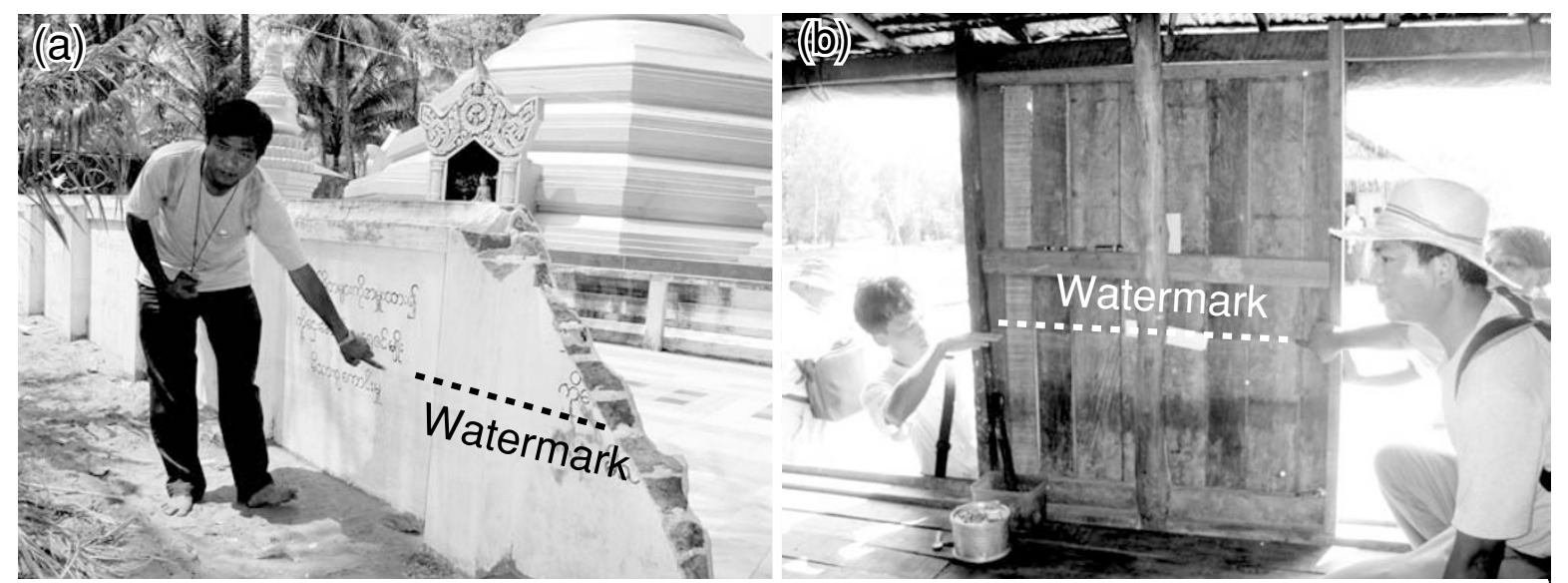

(c)
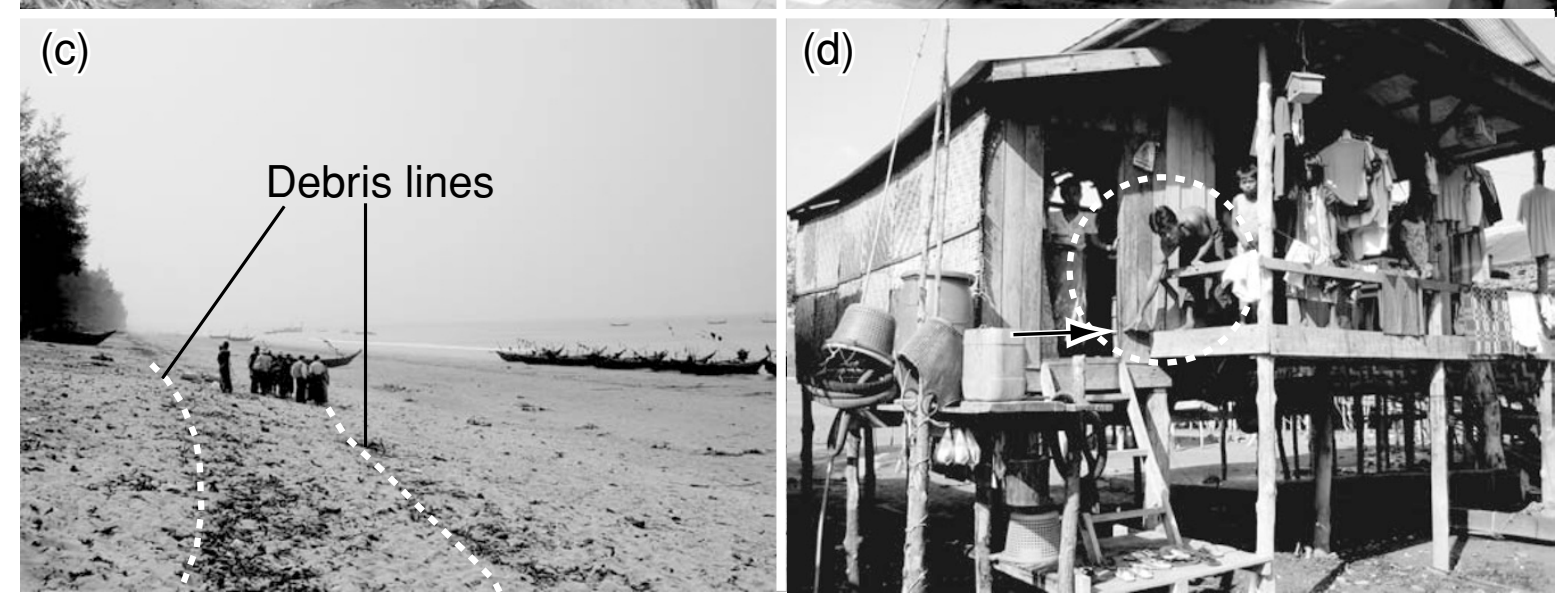

Fig. 2. Indicators of tsunami heights (a) Watermark left on wall surrounding Pagoda (Kating Thaung Island, loc 20). (b) Watermark left inside a house at Konnamaing Chaungwa Village (loc 11). (c) Debris lines indicating inundation limits of tsunami and rainy season high tide at Maungmagan Beach (loc 1). (d) Eyewitness accounts indicating the tsunami height at Tannyopada Village (loc 12).

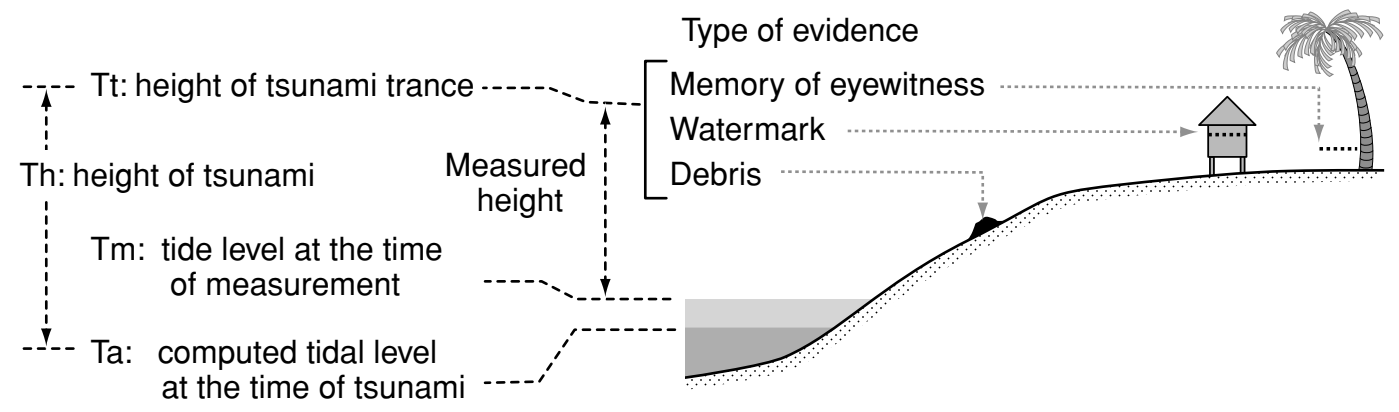

Fig. 3. Measurement of tsunami heights and corrections.

Many coastal residents compared the tsunami heights with the "rainy season high tide level". From the interviews, we had an impression that high tide levels are different in dry and rainy seasons. However, predicted astronomical high tide levels are more or less similar throughout a year. The rainy season high tide may be associated with storm surges, as we discuss in Section 7.

The survey results are compiled in Table 1 with location numbers, location names, latitudes and longitudes, the corrected and measured heights (in meter), type of measurements ( $\mathrm{R}$ for runup and I for inundation), type of evidence ( $\mathrm{D}$ for debris, $\mathrm{E}$ for eyewitness accounts, W for watermarks), reliability (A is based on physical evidence supported by eyewitness accounts, B is based on eyewitness accounts only), tsunami arrival times based on interviews, measurement time, computed tide at the measurements (in meter), assumed tsunami arrival time and calculated tide for the corrections (in meter).

\section{Ayeyarwaddy Delta}

A total of six localities (loc 17 to 22) near Pyinsalu were surveyed (Fig. 5) in Ayeyarwaddy Delta. In this region, 25 people lost their lives and 1,130 people were affected. The tsunami arrival times were between 11:00 and 11:45 am, according to eyewitness accounts. We assume that the tsunami arrival time was 11:30 am, when the tide level was $1.9 \mathrm{~m}$, for the entire region for the correction of tsunami heights. If the tsunami arrival was 11:00 or 11:45, when 


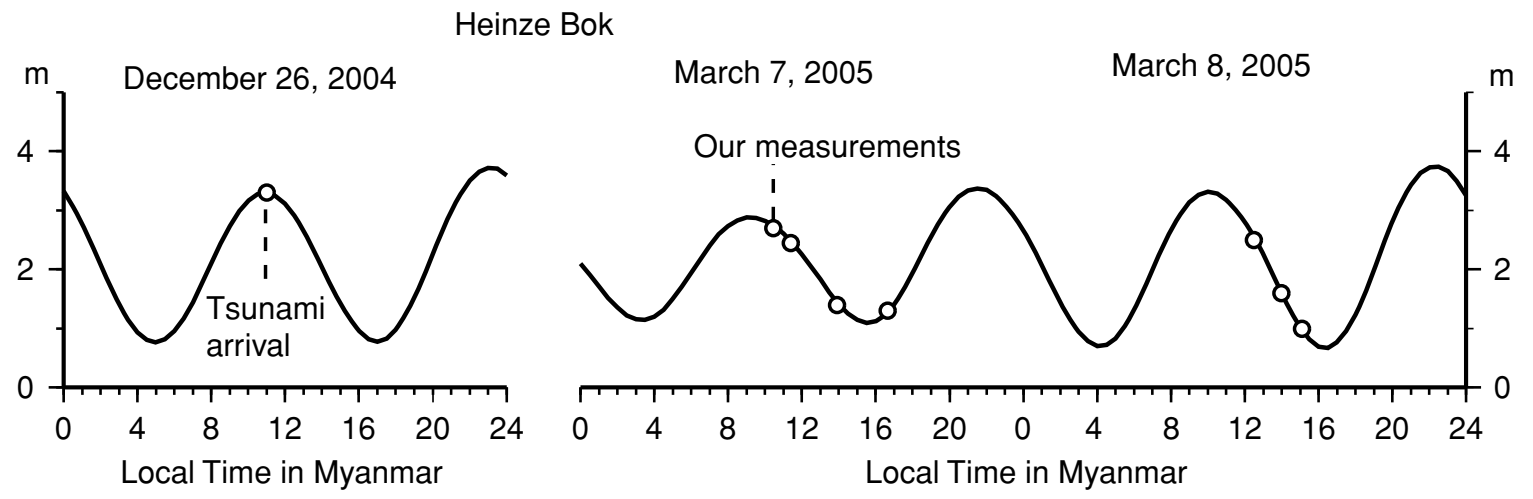

Fig. 4. Predicted astronomical tidal changes at Heinze Bok (Long Island), near Dawei. (a) Tidal change on December 26, 2004. An open circle on the curve shows the time of the tsunami arrival. (b) Tidal change on March 7-8, 2005. Circles on the curve show times of our measurements.
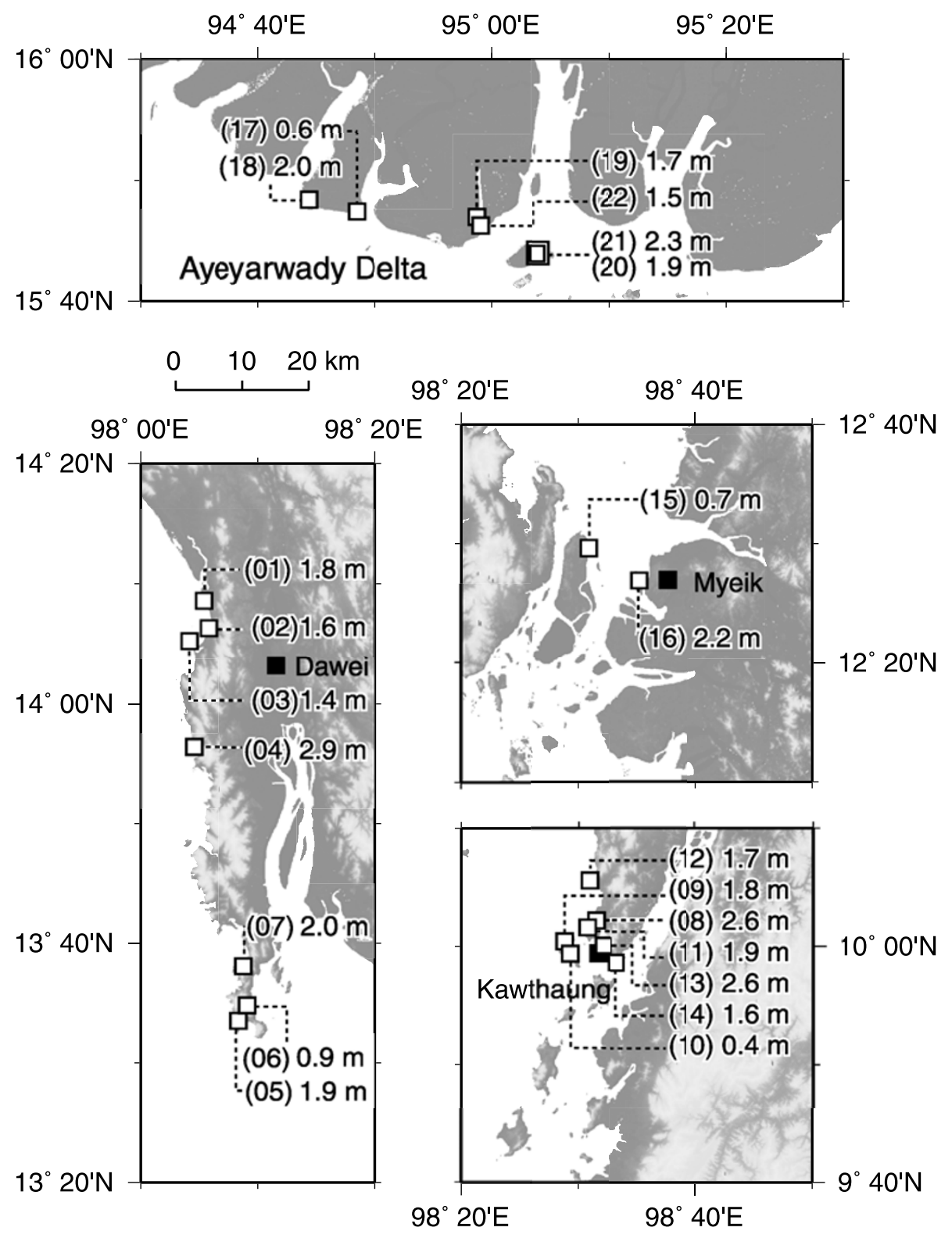

Fig. 5. Tsunami survey locations. Location numbers (in parenthesis) and corrected heights are shown at each location. 


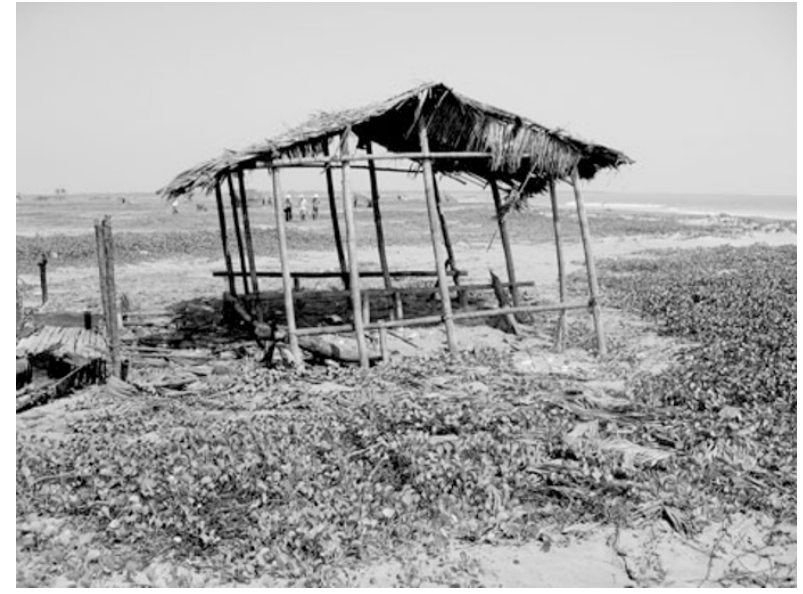

Fig. 6. Damaged hut in Kapyet Thaung Village.

the tide levels were $2.0 \mathrm{~m}$ and $1.8 \mathrm{~m}$, the corrected heights would be lower or higher by $0.1 \mathrm{~m}$, respectively.

At Layyin Kwin Village (loc 17), 16 huts out of 20 were washed away and one person was perished by the tsunami (Fig. 6). According to an eyewitness, the tsunami arrived at 11:45, when the tide was low, in four waves. The inundation depth was about $20 \mathrm{~cm}$. Our measurement indicated that the tsunami level was $0.7 \mathrm{~m}$ above the sea level, or $0.6 \mathrm{~m}$ after the correction for tide.

Kapyet Thaung Village (loc 18) is highly affected by the tsunami. Almost all of 130 huts were washed away and 17 casualties were reported. Some ships were dragged over inland. According to an eyewitness account, the tsunami arrived at $11 \mathrm{am}$ in three waves with 15 minute intervals. Our measurement indicated that the tsunami height was $3.5 \mathrm{~m}$ above the sea level, or $2.0 \mathrm{~m}$ after the correction.

Thit Poke (loc 19) is a small village with 332 houses and located at about $20 \mathrm{~km}$ from Pyinsalu. Two houses were damaged, but the tsunami caused no injuries or casualties. Interview with local people indicated that the tsunami inundated about $50 \mathrm{~cm}$ above ground at 11:40 am. The measured height was $2.9 \mathrm{~m}$ above the sea level and the corrected height is $1.7 \mathrm{~m}$.

In Kaing Thaung Island Village, a pagoda built near the shoreline was damaged by the tsunami (loc 20). Part of the outer wall was knocked down and watermark was clearly observed at $50 \mathrm{~cm}$ above the ground level (Fig. 2(a)). A Buddhist monk told us that the tsunami arrived at 11:30 am. Our measurement indicated that the tsunami height was $1.8 \mathrm{~m}$ above the sea level, or $1.9 \mathrm{~m}$ after the correction. In this village, 8 casualties and 16 damaged houses are reported. In one of the houses, an eyewitness account indicated that the tsunami height was $1.35 \mathrm{~m}$ above the ground (loc 21). Our measurement indicated that the tsunami height was $2.0 \mathrm{~m}$ above the sea level, or $2.3 \mathrm{~m}$ with the correction.

In Aung Hlaing Village (loc 22), an eyewitness account indicated that the tsunami arrived at 11:45 am in two waves. The tsunami inundated about $60 \mathrm{~cm}$ above the ground. The second wave caused damage to 55 houses without any fatalities. The measured and corrected tsunami heights were $1.2 \mathrm{~m}$ and $1.5 \mathrm{~m}$, respectively.

\section{Dawei Area}

In the Dawei area, seven sites, loc 01 through loc 07, were surveyed (Fig. 5). The eyewitness accounts on the tsunami arrival time are variable. We assume that the tsunami arrived at 11:00, when the tide was highest in the morning $(3.3 \mathrm{~m})$. If the tsunami arrival was 1.5 hours earlier $(9: 30)$, then the tide level was $3.0 \mathrm{~m}$. If it was 1.5 hours later (12:30), then the tide level was $2.9 \mathrm{~m}$. The corrected tsunami height would be higher by $0.3 \mathrm{~m}$ and $0.4 \mathrm{~m}$, respectively.

On Maungmagan beach (loc 01), two parallel lines of debris were observed (Fig. 2(c)). A local fisherman told us that the lower debris line was formed by the December tsunami. He did not feel the earthquake but observed that the tsunami arrived at around $2 \mathrm{pm}$, in a total of four successive waves with 3 to $4 \mathrm{~m}$ height. The tsunami arrived at low tide and did not exceed the high tide level of the rainy season (the higher debris line). Another eyewitness indicated the tsunami arrival times to be at 10 am and 12 noon. Our measurement indicated that the lower and higher debris lines were $2.4 \mathrm{~m}$ and $2.9 \mathrm{~m}$ above the sea level at the time of measurement. The dune, to which the tsunami did not reach, was $4.0 \mathrm{~m}$ high. The corrected tsunami height becomes $1.8 \mathrm{~m}$.

Thabawseik-Kyauksent Village (loc 02) is a coastal village of about 200 houses which builds up very close to the shoreline. The interview with a local man confirmed that the tsunami reached up to $55 \mathrm{~cm}$ above the ground and arrived between about noon and $1 \mathrm{pm}$ in three successive waves of 20 minute intervals but caused no severe damage. The tsunami height was lower than the rainy season high tide level. Our measurement indicated that the tsunami height was $2.4 \mathrm{~m}$ above the sea level, or $1.6 \mathrm{~m}$ with the correction.

Myaw Yit Gyi Pagoda (loc 03) is situated on a small granite island and connected to the opposite bank by a concrete bridge. A Buddhist monk from the Pagoda told us that he did not feel the earthquake shaking. Between 9:30 and 11:30 am, he observed that three waves coming from different directions reached at the base of the bridge. The height of tsunami was larger than the high tide of the rainy season. When receded, the seafloor was exposed about $200 \mathrm{~m}$ from the shoreline. The tsunami height was measured as $3.3 \mathrm{~m}$ above the sea level, and the corrected tsunami height becomes $1.4 \mathrm{~m}$.

Sann Lan Village (loc 04) is also situated on the same shoreline, and constituted of almost all wooden houses. A fisherman told us that the tsunami arrived at 11 am in four times with 15 minute intervals, and it was coincidence with low tide. The measured tsunami height was $4.9 \mathrm{~m}$ above the sea level, or $2.9 \mathrm{~m}$ after the correction.

Kyet Lut beach (loc 05) is situated on the southern tip of the peninsula, $60 \mathrm{~km}$ from Dawei. Two parallel debris lines were observed on the beach. A young man, who seasonally live in a cottage, reported that the tsunami entered after lunch (normally, local people take lunch about $10 \mathrm{am}$ ), and observed three times with 3 to 5 minute intervals. The lower debris was brought by the tsunami, while the upper one was by rainy season high tide. Our measurement indicated that the lower debris line was $2.7 \mathrm{~m}$ above the sea level. The 
corrected tsunami height becomes $1.9 \mathrm{~m}$.

Kyaukmattat Village (loc 06) is situated on the west bank of the Dawei River. A fisherman mentioned that a receding wave firstly came around $1 \mathrm{pm}$ and then another high tide appeared at $8 \mathrm{pm}$. He indicated that the tsunami height was about $20 \mathrm{~cm}$ above ground on the wooden structure. Our measurement indicated that the tsunami height was $2.6 \mathrm{~m}$ above the sea level, or $0.9 \mathrm{~m}$ after the correction.

Nyawbyin Village (loc 07) is situated on the western coast of the peninsula in Longlon Township and its curved beach is surrounded by two ridges. Most people did not feel the earthquake but noticed that the tsunami arrived there around noon. Our measurement indicated that the tsunami height was $4.3 \mathrm{~m}$ above the sea level, or $2.0 \mathrm{~m}$ with correction.

\section{Myeik Area}

Myeik is the capital of Taninthayi division and situated between Dawei and Kawthaung. A chain of small islands called Myeik archipelago trending in a north-south direction is situated to the west of Myeik City. Two localities, Thandar Kyun and Pahtaw Villages (loc 15 and 16), were surveyed (Fig. 5).

The tsunami arrival times by eyewitness accounts differ by an hour. For the correction, we assume that the tsunami arrival time was 11:00, when the calculated tide was $4.2 \mathrm{~m}$. If the tsunami arrival was 12:00, when the tide level was $3.7 \mathrm{~m}$, then the corrected tsunami height would be higher by $0.5 \mathrm{~m}$.

At Thandar Kyun Village (loc 15), a man told us that the tsunami arrived at $11 \mathrm{am}$, in two waves with a 20 minute interval. Our measurement of the tsunami levels of two accounts were $2.2 \mathrm{~m}$ and $4.4 \mathrm{~m}$. Adopting the higher level, the corrected maximum tsunami height becomes $0.7 \mathrm{~m}$.

Pahtaw Village (loc 16) is located on a small island, a few kilometers west of Myeik City. An eyewitness reported that the tsunami arrived at 12 noon in three waves. Our measurement indicated that the tsunami height was $6.7 \mathrm{~m}$ above the sea level, or $2.2 \mathrm{~m}$ with correction. An eyewitness indicated that the tide level just before the tsunami arrival was $4.6 \mathrm{~m}$, making the tsunami height $2.1 \mathrm{~m}$, very similar to the corrected height.

\section{Kawthaung Area}

Kawthaung City is located at the southern tip of Myanmar, and its surrounding islands are reportedly affected by the tsunami. Total of seven localities along coastal areas of Kawthaung Township, including three islands (loc 8 to 10 ) and western coast of Kawthaung (loc 11 to 14) were surveyed (Fig. 5).

The eyewitness accounts of tsunami arrival were also variable between 10:30 and 11:45 am. We assume that the tsunami arrival was 11:00 (when the tide level was $2.9 \mathrm{~m}$ ) throughout the Kawthaung area. If the tsunami arrival was earlier or later by half an hour, i.e., at 10:30 and 11:30 when the tide levels were $3.0 \mathrm{~m}$ and $2.7 \mathrm{~m}$, then the corrected tsunami heights would be either $0.1 \mathrm{~m}$ lower or $0.2 \mathrm{~m}$ higher, respectively.

Plautonton Island is a small island close to the west coast of the Kawthaung City, connected by a $600 \mathrm{~m}$ long wooden

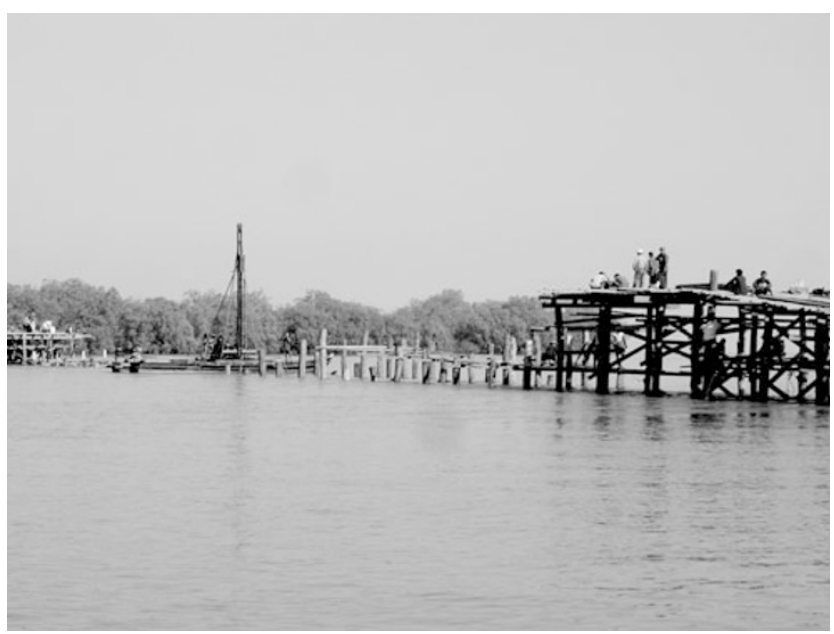

Fig. 7. Destruction of wooden bridge to Plautonton Island.

bridge. The central part of the bridge was destructed by the tsunami (Fig. 7). Measurement was taken at Plautonton Village (loc 08) on the island. Most houses of the village are built on a mudflat, raising floor level up to one or two meters above the sea surface. Watermark was observed at the interviewee's house. A housewife told us that the tsunami arrived at 10:30 am in three waves with 15 minute intervals. An owner of a grocery store said that two waves with 10-15 minute interval arrived. Because the tsunami arrived during low tide, there was no severe damage to buildings, but some household wares (rice bags, cloths and TV sets, etc) were flooded. One person died in this village. Our measurement indicated that the tsunami height was $1.8 \mathrm{~m}$ above the sea level, or $2.5 \mathrm{~m}$ after the correction.

At the Ywarthaya Village of Salonlay Island (loc 09), situated to the west of the Plautonton Island, there was no damage. A young man told us that the tsunami arrived at 11:15 am. Three to four waves arrived with 5 minute intervals. Our measurement indicated that the tsunami height was $1.0 \mathrm{~m}$ above the sea level, or $1.8 \mathrm{~m}$ after the correction.

The Dolphin Club of Salon Island (loc 10), a few kilometers south of Salonlay Island, has a flat shoreline. A young man told us that tsunami arrived at 11:45 am, in four waves with 5 minute intervals, and the height was the same as the sea level at the time of our visit. The corrected tsunami height becomes $0.4 \mathrm{~m}$, the lowest among the surveyed sites.

Konnamaing Chaungwa Village (loc 11) is a small village located on the western coast, northwest of Kawthaung City. A bridge over a stream connected to the village is partly damaged during the incoming tsunami. There were some damages by the tsunami: one death and destruction of eight houses. There is a clear watermark on a wall of a house indicating the tsunami height (Fig. 2(b)). Furthermore, the tsunami brought up some fishing boats along the stream course and then onto the paddy field. Some traces of marine mud on telephone post indicated the height of splash from the tsunami. According to eyewitness account, the tsunami arrived at 10:45 am. Our measurement indicated that the two watermarks were 1.4 and $1.2 \mathrm{~m}$ above the ground level, or $3.9 \mathrm{~m}$ and $4.0 \mathrm{~m}$ above the sea level. The corrected maximum tsunami height becomes $1.9 \mathrm{~m}$. 


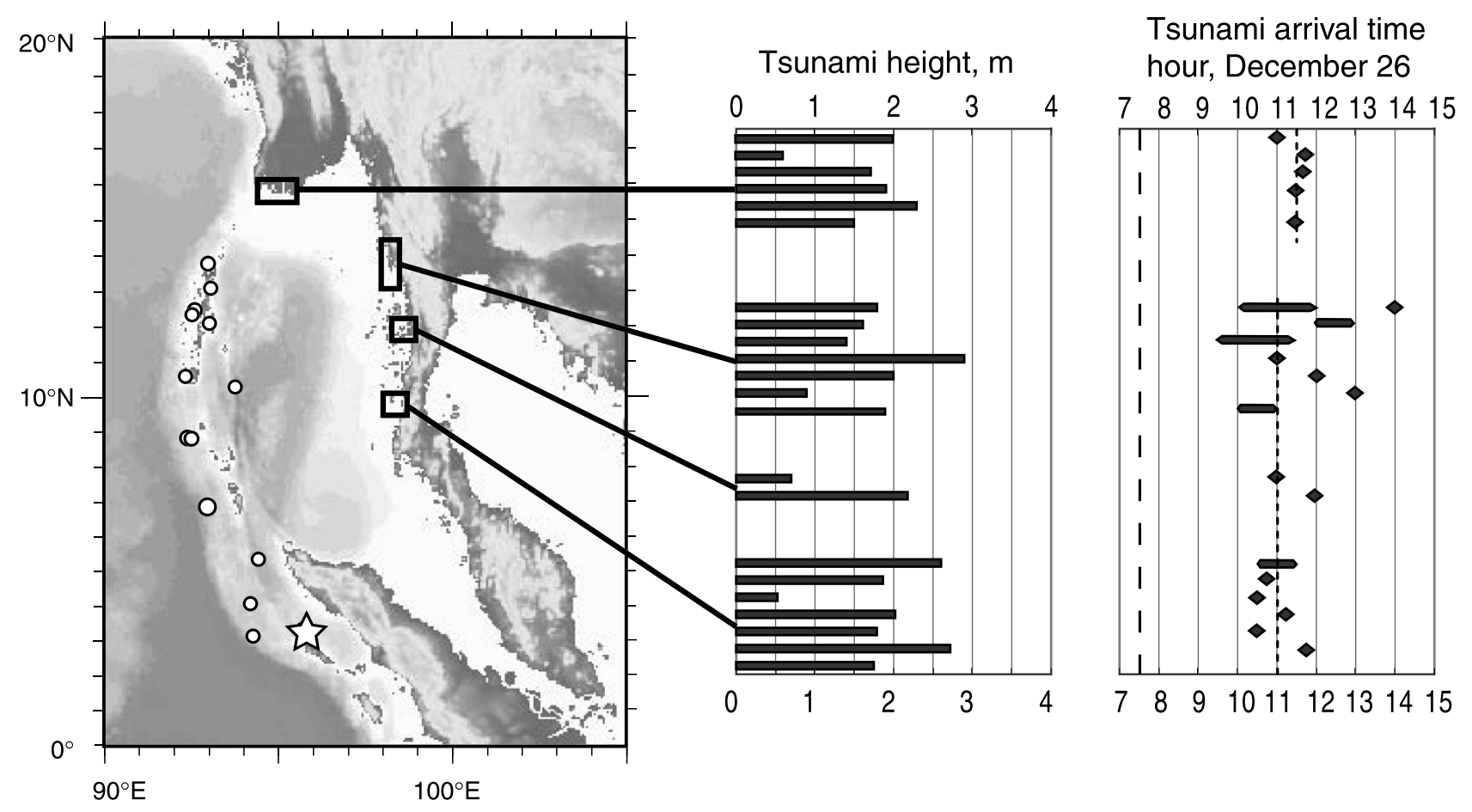

Fig. 8. Summary of tsunami survey. The left map shows the epicenter of the mainshock (star) and 1-day aftershocks (circles) according to U.S.G.S. The center panel is the corrected tsunami heights. The right panel indicates the tsunami arrival times according to eyewitness accounts. The vertical dashed and dotted lines show the earthquake origin time and the assumed arrival times for the tide corrections, respectively.

Tannyopada Village (loc 12) is a small village of 40 houses located along the shoreline northwest of Kawthaung City. A man told us that the tsunami arrived between 10:30 and $11 \mathrm{am}$, in three times with 10 minute intervals (Fig. 2(d)). Our measurement indicated that the tsunami height was $4.4 \mathrm{~m}$ above the sea level, or $1.7 \mathrm{~m}$ after the tide correction. The sea level was very low at the time of our measurement and the water front was more than $200 \mathrm{~m}$ offshore, hence the height measurement was less reliable.

At Thirimyaing Quarter of Kawthaung (loc 13), a young female told us that the tsunami arrived at 10:30 am, in five times with 5 minute intervals. Our measurement indicated that the tsunami height was $3.3 \mathrm{~m}$ above the sea level. The calculated tide levels at the time of measurement and at 11:00 of December 26 are $0.2 \mathrm{~m}$ and $2.9 \mathrm{~m}$, respectively, hence the corrected height would be $0.6 \mathrm{~m}$. However, the sea level at the time of measurements was very low, and the measured heights are not reliable. Alternatively, we estimate the tsunami heights using the differential levels at this location. According to eyewitness accounts, the tsunami height was $1.8 \mathrm{~m}$ higher than the high tide level in the morning of March 10 (our measurement day). The calculated high tide of the day is $3.7 \mathrm{~m}$, or $0.8 \mathrm{~m}$ higher than 11:00 of December 26. From these, the tsunami height is estimated as $2.6 \mathrm{~m}$. We consider that this estimate is more reliable.

Myoma Jetty of Kawthaung (loc 14) is a harbor for domestic transportation near the center of Kawthaung City. Many people noticed the abnormal rise of sea level and reported that the highest tsunami level was about $30 \mathrm{~cm}$ below the top of the quay wall. The measured and corrected tsunami heights were $4.1 \mathrm{~m}$ and $1.6 \mathrm{~m}$, respectively.

\section{Tsunami Heights along the Myanmar Coast}

Survey data of the 22 localities (loc 01 to 22) from Ayeyarwaddy Delta through Taninthayi Division reveal that tsunami heights along the Myanmar coast were between 0.4 and $2.9 \mathrm{~m}$ and the tsunami arrival times were mostly between 9:30 and 13:00, that is 2 to 5.5 hours after the earthquake (Table 1 and Fig. 8). The arrival times are highly variable in the same area, indicating that the reported times depend on the interviewees. Among the eyewitness we interviewed, nobody felt the earthquake shaking, making it difficult to estimate the time between the earthquake and tsunami.

Eyewitness often compared the December tsunami heights with the "rainy season high tide"; at most locations, the tsunami height was similar or smaller than the "rainy season high tide" level. As already mentioned in Section 2, however, the calculated high tides are more or less similar throughout a year. Seasonal change in sea level may be due to seasonal change in the wind direction. In Andaman Sea, the SW wind toward land is dominant in rainy (Monsoon) season (from June through September), while the NE wind toward ocean is dominant in other seasons. The sea level change due to the Monsoon wind is about $20 \mathrm{~cm}$ according to a Global Circulation Model, and the sea level change due to atmospheric pressure change is estimated as about $10 \mathrm{~cm}$ (M. Hirabara, Meteorological Research Institute, personal communication). The seasonal change in Sea Surface Height measured by a satellite in the central Andaman Sea is about $10 \mathrm{~cm}$ (N. Usui, Meteorological Research Institute, personal communication). Hence the amplitudes of sea level change due to Monsoon wind are smaller than the daily tidal changes. A possible cause 


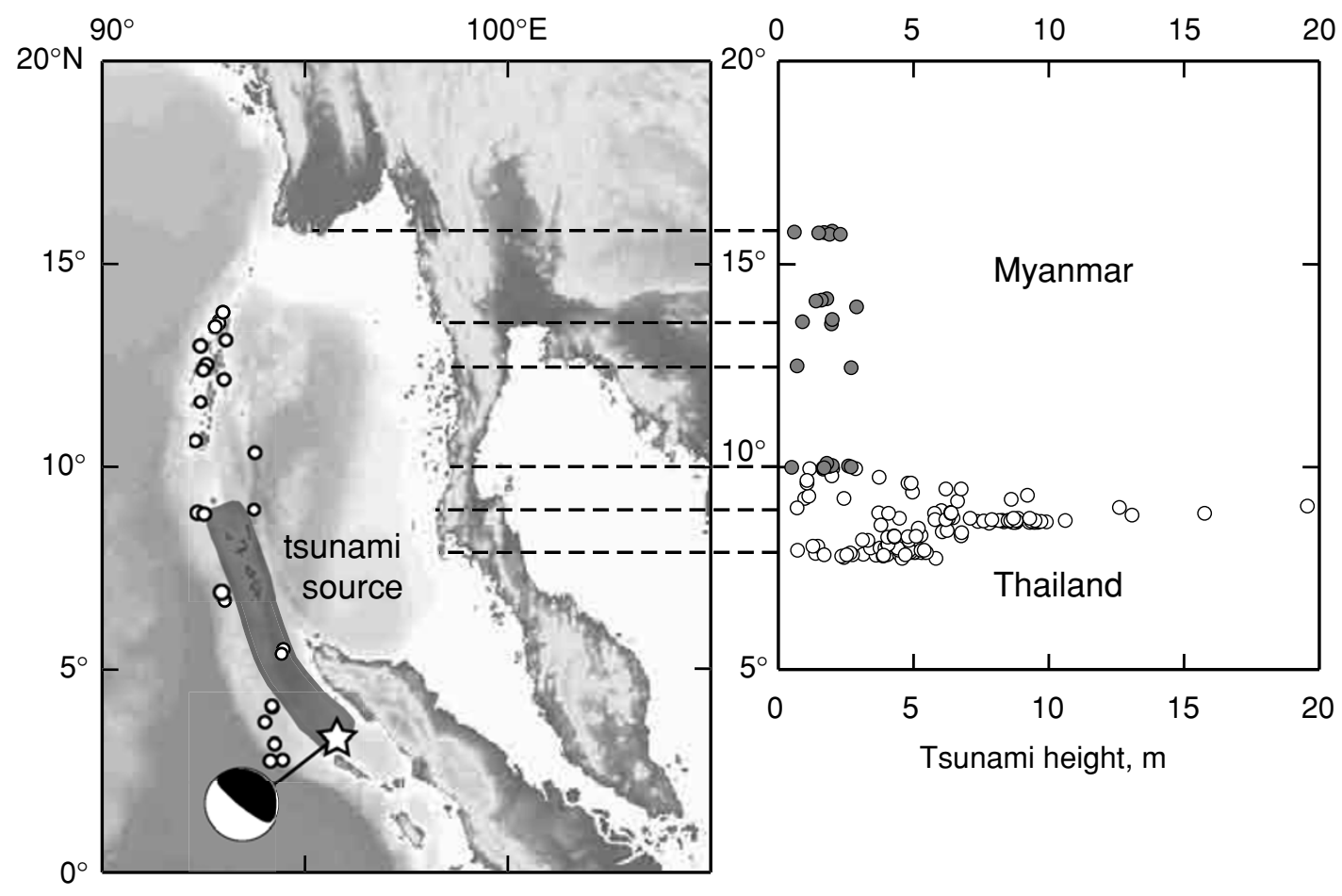

Fig. 9. Comparison of tsunami heights along the Myanmar and Thai coasts. The tsunami heights along the Thai coasts were surveyed by Matsutomi $e t$ al. (2005), Satake et al. (2005), and Tsuji et al. (2006). Inferred tsunami source area is shown.

for the sea level change and the observed debris deposition may be caused by a storm surge associated with Cyclones before and after the rainy season. In fact, during May 1719, 2004, wind speed for more than $20 \mathrm{~m} / \mathrm{s}$ was observed along the Andaman Sea coast (according to QuickScat data: http://www.ssmi.com/qscat/), and such a wind might have caused storm surges.

The tsunami height was much smaller than those of the neighboring Thai coast (Fig. 9). The tsunami heights along the Thai coast were measured by three Japanese parties (Matsutomi et al., 2005; Satake et al., 2005; Tsuji et al., 2006). From south to north along the Andaman Sea, the reported tsunami heights are about $5 \mathrm{~m}$ in Phuket, more than $10 \mathrm{~m}$ around Khao Lak where thousands of European tourists lost their lives, and nearly $20 \mathrm{~m}$ at Ban Thung Dap, then are smaller toward the Myanmar border. The relatively smaller tsunami heights in Myanmar explain why the tsunami casualties, as reported as 71, were much smaller than those of Thailand. One of the reasons for the smaller tsunami may be due to the fact that some coast of Taninthayi Division was protected by offshore islands of the Myeik Archipelago trending in the north-south direction.

\section{Computation of Tsunami Arrival Times and Relative Amplitudes}

The tsunami source was estimated to be about $700 \mathrm{~km}$ long from analysis of tide gauge records (Lay et al., 2005). We computed tsunami arrival times and maximum amplitude from a simple source model of $700 \mathrm{~km} \mathrm{long}$ and $100 \mathrm{~km}$ wide. For the computation, we used ETOPO2 bathymetry grid (interval is 2 minutes of the arc or about $3.7 \mathrm{~km}$ ) estimated from satellite observation (Smith and

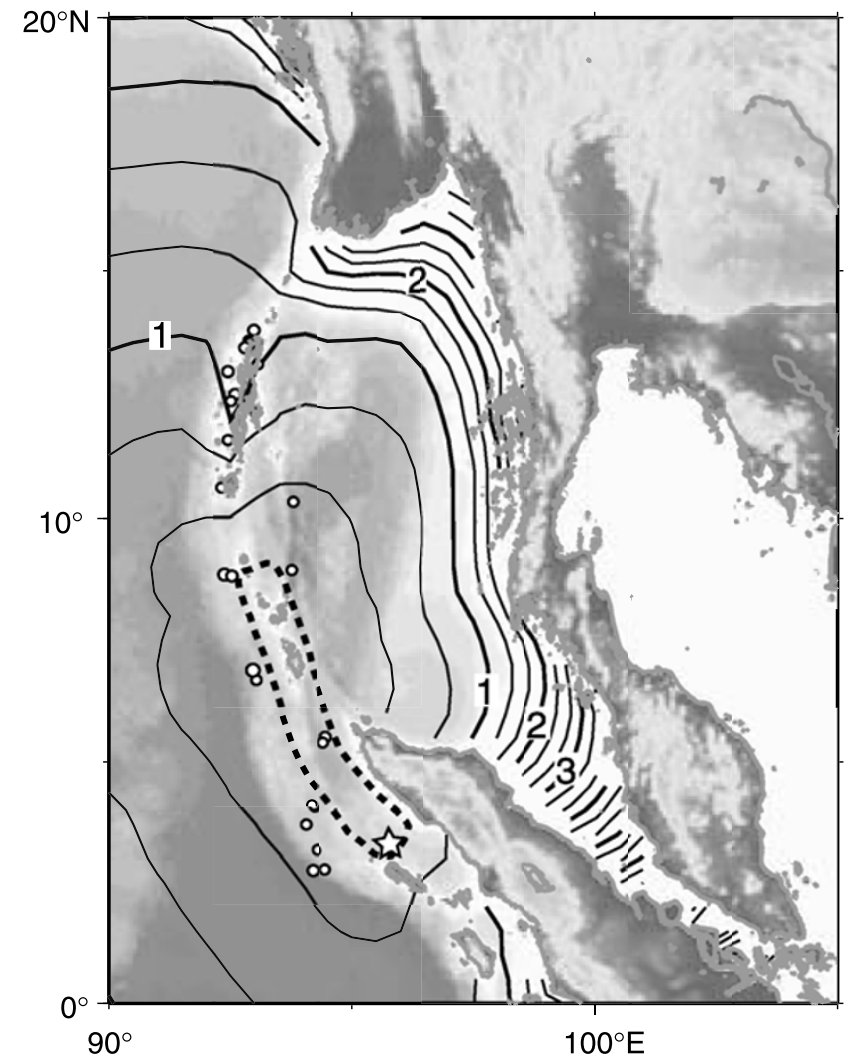

Fig. 10. Tsunami arrival times computed from a $700 \mathrm{~km}$ long tsunami source. Counter interval is 20 minutes with labels at each hour. The epicenter (star), 1-day aftershocks (circles) and the assumed tsunami source (dotted curve) are also shown. 


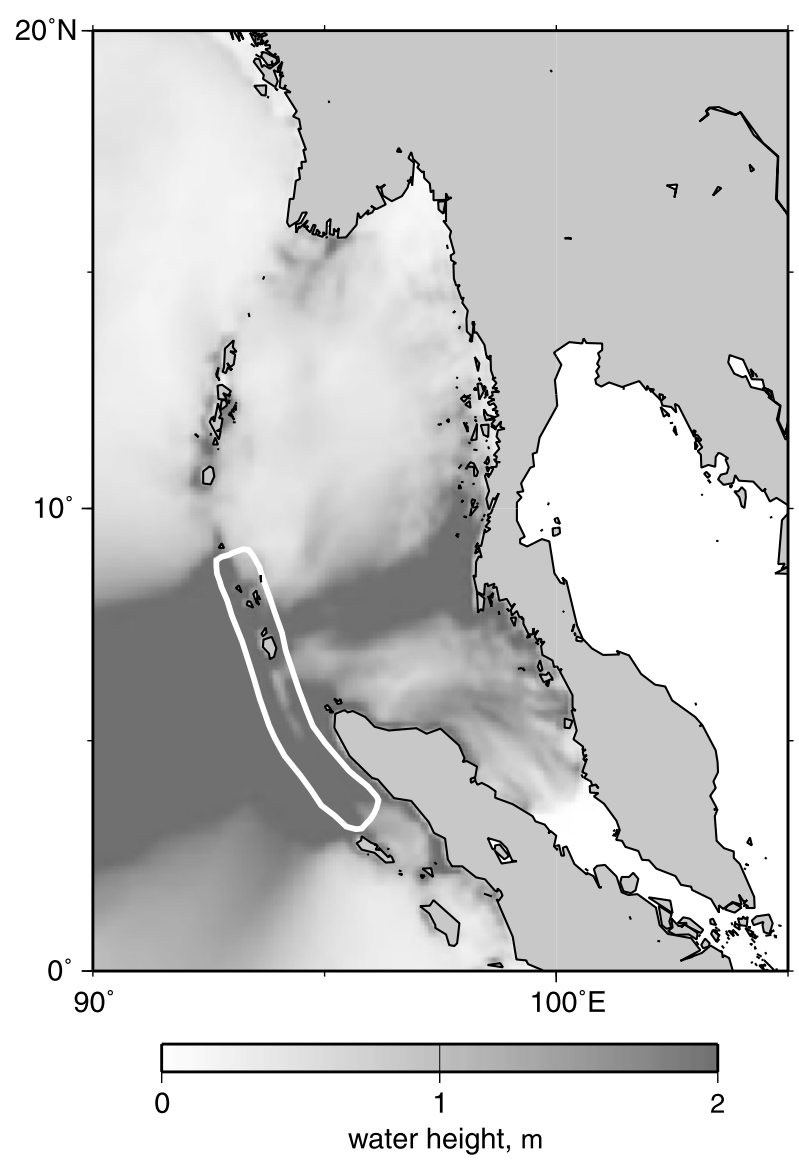

Fig. 11. Distribution of maximum tsunami heights computed from a 700 $\mathrm{km}$ long tsunami source. The assumed source region is also shown.

Sandwell, 1997). The tsunami travel times were computed on the basis of Huygens' principle, using software $\mathrm{ttt}$ (tsunami travel time) version 2.2. The maximum amplitudes were computed by using finite-difference method of the linear long-wave equation (e.g., Satake, 2002).

The computed tsunami travel times (Fig. 10) shows that the tsunami travel times to the Myanmar coast are 2.5 hours or more, indicating that the first tsunami was expected at around $10 \mathrm{am}$. Because of lack of ground shaking and the relatively small size of tsunami, coastal residents might not have noticed the tsunami at the first arrival.

The tsunami source extending in the north-south direction affects the amplitude distribution. Figure 11 shows the distribution of computed maximum amplitudes. The tsunami amplitudes are larger in the northeast direction toward Phuket and southwest direction toward Maldives. The computed tsunami amplitudes are relatively smaller along the Myanmar coast. The amplitudes are slightly large off Ayeyarwaddy Delta, probably because the shallow delta extends to offshore to cause concentration of tsunami energy.

\section{Conclusion}

The tsunami heights from the 2004 December earthquake were not more than $3 \mathrm{~m}$ along the Myanmar coast, which brought relatively moderate tsunami damage to Myanmar compared with other countries such as Indonesia, Thailand, Sri Lanka and India. Numerous houses, including seasonal huts, are built along the Myanmar coasts without any protection for tsunamis. Our interviews indicate that the people did not feel earthquake in Taninthayi Division or in Ayeyarwaddy Delta. The only way to notify people about the tsunami danger is through Tsunami Warning System. However, infrastructure to disseminate the warning information is rather poor in Myanmar. In addition, coastal residents in most surveyed localities live on flat land along the coast, especially in the Ayeyarwaddy Delta, and there is no higher ground to evacuate. In order to prevent future tsunami hazards, evaluation of earthquake and tsunami potential in the northern extension of the Sunda subduction zone is needed. Study of historic and prehistoric tsunami events would be necessary for such evaluation.

Acknowledgments. Myanmar Department of Meteorology and Hydrology helped the Japanese scientists to visit Myanmar. The encouragement of the director general, San Hla Thaw, and the deputy director general Tun Lwin, and support by other officers and staffs, including those in the field offices of Dawei, Kawthaung and Myeik, were very helpful. Myanmar Engineering Society provided official invitation and logistic arrangement of the trip. We are grateful to the Chairman U Than Myint for his continuous support. Advices from members of Yangon University, Yangon Technological University, Myanmar Geoscience Society and Myanmar Engineering Society are greatly appreciated. Many people in the field helped our survey. In particular, Tin Hlaing (the former Township Administration Officer) accompanied for the surveys in Dawei, Kawthaung and Myeik areas and helped us arrange local logistics. The survey was supported by Special Coordination Funds for Promoting Science and Technology, from Japanese Ministry of Education, Sports, Culture, Science and Technology. About the seasonal change in wind and sea level in Myanmar, Drs. Okada, Yamazaki, Nakazawa, Hirabara and Usui at Meteorological Research Institute provided valuable information.

\section{References}

Intergovernmental Oceanographic Commission, Post-tsunami Survey Field Guide, Manuals and Guides No. 37, 62 pp., UNESCO, 1998.

International Federation of Red Cross and Red Crescent Societies, World Disasters Report, 246 pp., Kumarian Press, 2005.

Lay, T., H. Kanamori, C. J. Ammon, M. Nettles, S. N. Ward, R. C. Aster, S. L. Beck, S. L. Bilek, M. R. Brudzinski, R. Butler, H. R. DeShon, G. Ekström, K. Satake, and S. Sipkin, The Great Sumatra-Andaman Earthquake of 26 December 2004, Science, 308, 1127-1133, 2005.

Matsutomi, H., T. Takahashi, M. Matsuyama, K. Harada, T. Hiraishi, S. Supartid, and S. Naksuksakul, The 2004 Off Sumatra Earthquake Tsunami and Damage at Khao Lak and Phuket Island in Thailand, Annual J. Coastal Engineering, JSCE, 52, 1356-1360, 2005 (in Japanese).

Satake, K., Tsunamis, in International Handbook of Earthquake and Engineering Seismology, edited by W. H. K. Lee, H. Kanamori, P. C. Jennings, and C. Kisslinger, 81A, 437-451, 2002.

Satake, K., Y. Okamura, M. Shishikura, Than Tin Aung, and K. Fujima, Tsunami field survey along Thai coast from the 2004 Sumatra-Andaman earthquake, Annual Report on Active Fault and Paleoearthquake Researches, Geological Survey of Japan/AIST, No. 5, 161-188, 2005.

Smith, W. H. F. and D. T. Sandwell, Global sea floor topography from satellite altimetry and ship depth soundings, Science, 277, 1956-1962, 1997.

Tsuji, Y., Y. Namegaya, H. Matsumoto, S.-I. Iwasaki, W. Kanbua, M. Sriwichai, and V. Meesuk, The 2004 Indian tsunami in Thailand: Surveyed runup heights and tide gauge records, Earth Planets Space, 58, this issue, 223-232, 2006.

United Kingdom Hydrographic Office, Admiralty Tide Tables, Volume 3: Indian Ocean \& South China Sea (including Tidal Stream Tables), 2004.

K. Satake (e-mail: kenji.satake@aist.go.jp), T. T. Aung, Y. Sawai, Y. Okamura, K. S. Win, W. Swe, C. Swe, T. L. Swe, S. T. Tun, M. M. Soe, T. Z. Oo, and S. H. Zaw 